Estudios de

lingüística inglesa aplicada

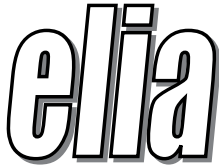

\title{
OFFICIAL BILINGUALISM AND INDIGENOUS LANGUAGE LOSS: THE CASE OF CAMEROON
}

\section{EL BILINGÜISMO OFICIAL Y LA EXTINCIÓN DE LAS LENGUAS INDÍGENAS: EL CASO DE CAMERÚN}

\section{Raymond Echitchi}

Universidad Católica San Antonio de Murcia

rechitchi@ucam.edu

DOI: http://dx.doi.org/10.12795/elia.mon.2019.i1.04

Cameroon is an African country whose complex linguistic and cultural situation has attracted a lot of interest in academia. From the early days of independence, decision-makers in Cameroon have attempted to find ways to promote a peaceful coexistence between the various languages and cultures within the country. Nevertheless, they have mostly encouraged the use of two colonial languages as evidenced by the country's dual system of education. Though the dominance of English and French in Cameroon's education has had positive effects such as opening the country to the world, it has also contributed to the marginalisation and gradual extinction of vernacular languages, which were spoken before the arrival of colonial masters. This paper therefore sets out to examine the reasons behind the overwhelming presence of European languages in Cameroon's education. It is also a call for the preservation of Cameroon's indigenous languages in a context where most of them are losing domains of use. Claims made in this paper are backed by a review of research works on Cameroon's language situation, a description of Cameroon's 
education system, and an observation of the country's linguistic and cultural dynamics. The foregoing shall be complemented by the author's first-hand experience and continuous contact with teachers and other educational stakeholders.

Keywords: Bilingualism, education, indigenous languages, Cameroon

Camerún es un país africano cuya compleja situación lingüistica y cultural siempre ha atraido mucho interés por parte de los investigadores. Desde la independencia del país, los sucesivos gobiernos han intentado fomentar la convivencia pacifica entre las diferentes lenguas y culturas. Sin embargo, este noble propósito dio lugar a la promoción exclusiva de las dos lenguas coloniales como lo demuestra el sistema educativo actual del país. Pese a haber tenido algunos efectos positivos como la apertura del país al mundo, el monopolio del inglés y el francés en la educación de Camerún dio lugar al aislamiento y a la extinción gradual de los idiomas que se hablaban antes de la llegada de las potencias colonizadoras. Asi pues, este artículo examina las razones que subyacen a la situación privilegiada que ostentan las lenguas europeas en la educación en Camerún. También se hace un llamamiento para la conservación de los idiomas indigenas de Camerún en un contexto en el que la mayoría de ellos están a punto de desaparecer. Las afirmaciones que se hacen en este artículo están respaldadas por la revisión de diversos trabajos de investigación previos sobre la situación lingüistica de Camerún, una descripción del sistema educativo actual en Camerún y la observación de los cambios lingüisticos y culturales recientes en el país. Esto se complementará con la experiencia propia del autor y así como su continuo contacto con maestros y otros miembros de la comunidad educativa del país.

Palabras clave: Bilingüismo, educación, lenguas indigenas, Camerún

\section{Introduction}

This article is a description and evaluation of Cameroon's language situation with great emphasis on the country's bilingual educational system and how it has contributed to consolidating an uneasy relationship between the different languages that make up the country's linguistic fabric. Cameroon is a country whose history has determined and shaped

ELIA Mon. I, pp. 65-88 DOI: http://dx.doi.org/10.12795/elia.mon.2019.i1.04 
the challenges it currently faces, especially when it comes to language dynamics and education. Therefore, an overview of the country's history is a necessary step to take when analyzing its education system(s). In addition, education in Cameroon itself is a complex issue which can be utilized to understand the benefits and drawbacks of bilingual education in multilingual and multicultural settings. In fact, bilingualism, as it is experienced nowadays in Cameroon, can be said to have caused more harm than good, as the country's bilingual education policy has overlooked indigenous languages, which are undoubtedly the backbones of Cameroon's identity.

This write-up is thus an academic review which is based on various sources, be they documentary, such as literature on educational dynamics in Cameroon, and ethnographic, like informal talks with educational stakeholders in the country as well as the author's first-hand experience of the situation being dealt with. The ultimate goal here is to provide readers with a good understanding of the country's language situation, while enabling them to grasp the extent to which Cameroon's bilingual education system has led to the destruction of indigenous languages. It will be divided into three parts; an overview of Cameroon's history, with an emphasis on the linguistic legacy of every major historical event in the country, a description of the country's educational system(s), with a close look at the role of languages in each subset of the country's educational environment, and a review of the reasons for the absence of indigenous languages in Cameroon's bilingual educational policy.

\section{An overview of Cameroon's history and language situation}

\subsection{Precolonial period}

Cameroon is an African country whose territory spans from the Bight of Biafra to Lake Chad. Given its geographical position, the country was at the crossroads of various migratory patterns long before the advent of colonialism. This multiplicity of migrations towards the territory known today as Cameroon contributed to making it a linguistically complex country whose populations speak vernacular languages belonging to three out of the four language families found on the African continent, namely the Niger-Congo; Nilo-Saharan and Afro-Asiatic groups (Anchimbe, 2005:

ELIA Mon. I, pp. 65-88 DOI: http://dx.doi.org/10.12795/elia.mon.2019.i1.04 
34, Echitchi, 2018: 17). Therefore, even before European colonialism, Cameroon was not a linguistically homogeneous entity but rather a territory within which ethnic groups from various parts of Africa coexisted and used various linguas francas for intertribal communication. Said linguas francas included Mungaka in the West, Duala in coastal and adjacent mountain areas, Fulfulde (or Fulani) along with Hausa, Kanuri and Shuwa Arabic in northern savannahs and a pidginized variety of Ewondo known as Mongo Ewondo in the forest zone (Echitchi, 2018:15). This situation was quite stable until the arrival of European sailors and the setting up of trading posts in Cameroon's coastal towns.

The first Europeans to set foot on Cameroon soil are said have been a group of Portuguese sailors headed by Fernao do Poo. As a matter of fact, history recounts that in 1472 do Poo arrived at the bottom of the Gulf of Guinea and was struck by the high amount of shrimp he found in the mouth of river Wouri. This led him to name the river Rio do Camaroes, meaning "River of Shrimp", and that is how the word which would later be used to refer to the country as a whole originated. After Fernao do Poo's arrival, many other European nationals became interested in Cameroon and carried out trading activities (including slave trade) and evangelization in the country. In 1858, a British missionary called Alfred Saker founded a mission which he called Victoria and started teaching the Christian faith to the indigenous tribes of Cameroon's coast. He was assisted in his endeavour by two black missionaries from the West Indies known as Joseph Merrick and Jackson Fuller.

\subsection{German Protectorate}

Though the English influence grew through constant interactions with indigenous people, the United Kingdom did not officially claim Cameroon as one of its colonies, though a group of traditional leaders had urged Britain to do so in a letter they addressed to Queen Victoria. Finally, following England's reluctance to consolidate the already close ties between them and Cameroon, a group of German traders, who had also been very active on the Cameroon coast started negotiating a political relationship with ethnic leaders and this led to Cameroon's becoming a German Protectorate in 1884. Though the signatories of the protectorate only represented villages found around the Wouri Estuary, the Germans went on to apply the so-called "hinterland doctrine" (Michalopoulos \&

ELIA Mon. I, pp. 65-88～DOI: http://dx.doi.org/10.12795/elia.mon.2019.i1.04 
Papaioannou, 2011) which basically meant that colonial powers having signed agreements with coastal people could claim inland territory until they met another colonial power. Therefore, the Germans extended their territory up to lake Chad to the North and the Congo and Ubangi rivers to the East and drew the map of what became known as German Kamerun. German rule lasted until the breakout of the first world-war and it is during this period that many plantations were set up in various parts of West Cameroon, leading to migrations from many parts of the country, which would contribute to shaping the country's language situations as explained below.

\section{Influence of the German occupation of Cameroon's language situation}

The German period did not only contribute to building Cameroon as a political entity, but also led to the consolidation of certain languages that had not been so important before. As a matter of fact, during the precolonial period, European missionaries and traders favoured indigenization through the use of the Duala language in their evangelization and commercial endeavours. That is exactly how the New Testament and many liturgy books were translated into Duala by British missionaries, and Duala became the lingua franca on and around Cameroon's Atlantic shores (Ndille, 2016). Nevertheless, returnees from Sierra Leone, who were often aides to the missionaries (and traders) from England and the West Indies, introduced their vernacular, that is, an English-based creole which started being used by the local population. Then, after the Germans annexed Cameroon, they developed large cash crop plantations and therefore had to bring labour from Cameroon's hinterlands, thus creating a situation where people from various ethnic and linguistic backgrounds found themselves working on the same plantations (Kouega, 2001). It is in this situation that an English-based pidgin, deriving from the vernacular spoken by those Sierra Leonean returnees started being used in cross ethnic communication, thus gaining ground to the point of completely overshadowing Duala which was confined to its role as a mere liturgical language. Though the Germans first attempted to impose their language by banning the use of all indigenous languages (Ndille, 2016), they realized that it was not possible to do without pidgin English, and thus decided to foster its use in informal situations while reiterating the obligation to use German in formal situations. Therefore, surprisingly enough, the main linguistic legacy of the Germans in Cameroon is not the spread of their language (which was

ELIA Mon. I, pp. 65-88 DOI: http://dx.doi.org/10.12795/elia.mon.2019.i1.04 
used only by a tiny minority of German-educated indigenes) but rather the growth of present-day Cameroon Pidgin English (also referred to as Kamtok or Cameroon Creole in academic settings), which of course borrowed some words from German (Weber, 2012) and Portuguese (Todd, 1982), though its vocabulary is undoubtedly English-based.

\subsection{British and French Domination}

At the outset of WWI, the allies started attacking German positions, not only in Europe, but also in Africa and around the world. At that time, German colonies in Africa included Cameroon, Tanganyika, RuandaUrundi, Togoland and South West Africa. German Cameroon in particular was surrounded by colonies belonging to France to the South and East, and the British colonies of Nigeria to the West. Thus, the Germans were easily encircled by French and British troops and were defeated two years before the war came to an end worldwide. By 1916 Cameroon had become a territory with a transitional French-English administration that was confirmed later by the League of Nations, which partitioned former German Cameroon into two territories: a British-administered territory along the border with Nigeria and a French-administered territory which shared borders with other colonies of French Equatorial Africa. Though British and French Cameroons had distinct political identities, they were administered as de facto parts of contiguous colonies under the authority of Britain and France respectively. In other words, British Northern and Southern Cameroons were administered as parts of British Northern Nigeria and British Eastern Nigeria (respectively) while French Cameroon was administered as part of French Equatorial Africa. This situation went on until the early sixties when British Southern Cameroons and French Cameroon reunited to form modern-day Cameroon, while British Northern Cameroons decided to unite with Nigeria, thus becoming parts of presentday Taraba, Adamawa and Borno states (A more detailed version of Cameroon's history can be found in Ngoh,1996).

\subsection{Cameroon's Language Situation}

After having established their rule in the former German protectorate of Cameroon, the French and the British went on to apply very distinct

ELIA Mon. I, pp. 65-88 DOI: http://dx.doi.org/10.12795/elia.mon.2019.i1.04 
language policies which would severely influence language dynamics in Cameroon after reunification. As a matter of fact, the French fostered the use of their language in education, administration and all official situations whereas the British enforced the use of English, while tolerating the use of Cameroon Pidgin English in non-official settings. French then became the main language spoken in French Cameroon, while English and Pidgin English gained ground in English Cameroon. Education became a reflection of those linguistic dynamics, as only English and French were used as mediums of instruction in British and French Cameroons respectively.

\section{Indigenous languages}

The less-privileged situation being experienced by indigenous languages can be said to have started during the British-French administration. In fact, though pre-colonial missionaries endeavoured to codify indigenous languages in order to use them in education, colonial administrators did not build on the foundations the missionaries had laid, though they hypocritically expressed willingness to do so (Ndille, 2016). In fact, given that most language teachers and other administrators came from Europe, (Nigeria or Sierra Leone in the case of British Cameroons) or were indigenes trained by colonial instructors, emphasis was laid on colonial languages (Anchimbe, 2006a). The use of indigenous languages became restricted to interactions between members of the same clan, and even in those situations, said languages were often shunned. In addition, the increasing use of English, French (and pidgin English in British Southern Cameroons and contiguous French Cameroon areas) contributed to the decrease in importance of African languages such as Duala, Mungaka, Ewondo (just to name a few), which until then had been used for crossethnic communication.

The relics of colonialists' emphasis on English and French can still be seen today as many Cameroonian languages are definitely on the brink of extinction (Eberhard et al., 2019), and many once vibrant languages have lost most domains of use they once enjoyed. In addition to taking away a very important part of Cameroon's rich language identity, the country's emphasis on colonial languages has led to increasing tensions between English and French speakers which have recently turned into a fight for self-determination (or better still secession) in the Englishspeaking part of the country.

ELIA Mon. I, pp. 65-88 DOI: http://dx.doi.org/10.12795/elia.mon.2019.i1.04 
The next section of this article will be aimed at presenting Cameroon's education system, while carefully analyzing the role of languages, be they indigenous or colonially-inherited languages.

\section{A Description of Cameroon's Education System(s)}

At first glance it is very difficult to define what we refer to as Cameroon's system(s) of education, as evidenced by our inability to choose between the singular or plural forms of the word "system". As a matter of fact, there are two schools of thought within the country, when it comes to describing the educational system. Some believe that Cameroon has an educational system (this is definitely the official narrative), while others, like Kouega who states that "Cameroon is a central African country where two systems of education operate simultaneously" (2003: 408), seem to suggest that there may actually two distinct systems of education within the country (an objective description and analysis may confirm this fact). As a matter of fact, when British Southern Cameroons and French Cameroon reunited, both territories came to the union with the distinct educational systems and curricula they had inherited from their colonial masters, and both systems have evolved quite separately up till today.

With the above being said, it can be stated that Cameroon has a dual system of education representing the colonial legacies of the respective territories that united to constitute the country. Nevertheless, it is worth noting that those differences are mostly seen in primary and secondary education, as harmonization has been achieved in higher education through immersion and the adoption of the Bachelor, Master and Doctorate/PhD (BMD) system since 2007. Therefore, only the French-speaking and English-speaking (sub) systems in primary and secondary schools will be described below.

\subsection{The French-speaking (Sub)system of Education}

This education system is the most widespread system in Cameroon as it is grounded in the former French-administered part of the country, which represents eight out of the country's ten regions. As most (if not all) education systems around the world, it is divided into three stages, namely primary, secondary and higher education.

ELIA Mon. I, pp. 65-88～DOI: http://dx.doi.org/10.12795/elia.mon.2019.i1.04 
Primary education spans from the so-called Section d'Initiation au Langage (SIL), which represents the first year, to Cours Moyen Deuxième Année (CM2) representing the sixth year of primary education. Before being admitted to a secondary education institution, Francophone primary school students are expected to have passed the Certificat d'Etudes Primaires (CEP), as well as a secondary school entrance examination known as Concours d'Entrée en Sixième, for those students who want to go to a public school. Students enrolling in private schools are exempted from sitting an entrance examination, whereas CEP is obligatory. When it comes to the medium of instruction in primary schools, in the past, teachers would resort to indigenous languages to teach children in early primary school but given the growing influence of French this practice is currently of no use in most parts of French Cameroon (except in remote parts of the East and northern regions).

Secondary education consists of seven years of education from Sixième to Terminale. Students completing the fourth year of secondary education have to take an official exam called Brevet d'Etudes du Premier Cycle (BEPC). Then, to be finally ready for higher education, the students have to pass the two stages of the Baccalauréat official exam, namely the so-called Probatoire, which is to be taken at the end of the sixth year of secondary education and Baccalauréat proper which is to be taken only by students who have passed the Probatoire exam.

As concerns languages, it is worth noting that the sole medium of instruction for content subjects is French in Francophone secondary schools, while English is taught as a foreign language throughout. From the third year of secondary education onwards, students can choose to take another foreign language, that is, Spanish, German, Arabic or even Chinese. There is also a small number of schools where Latin and Greek can be taken.

From the foregoing, it is clear that indigenous languages are poorly represented if not totally absent from Francophone schools. As a matter of fact, until the start of the experimental teaching of indigenous languages in 2011, they were not part of the official curriculum of Cameroon schools (Anchimbe, 2006a) and almost a decade later, observation confirms that the situation has not changed that much. Indigenous language education is still confined to a few pilot schools and non-official practice carried out by

ELIA Mon. I, pp. 65-88～DOI: http://dx.doi.org/10.12795/elia.mon.2019.i1.04 
organisations such as the Cameroon Association for Bible Translation and Literacy (CABTAL), the National Association of Cameroonian Language Committees (NACALCO) and SIL-Cameroon.

The rejection of vernacular languages started right after the French occupied the territory which became known as French Cameroon. As soon as they established their rule, the French started implementing a policy of direct assimilation whose aim was to make indigenes of Cameroon similar to people from mainland France (the so-called Metropole). Therefore, the French discouraged vehemently the teaching of vernacular languages, going to the extent of compelling missionary societies to change their language policies at the schools they ran or losing financial incentives they had been receiving from colonial authorities. Furthermore, schools that did not conform to the French-only policy were declared illegal and had to be closed (Anchimbe, 2006a; Ndille, 2016).

The situation described above continued after Cameroon gained independence from France and it is no wonder that French, along with English, continued to gain ground in a country with a vast array of indigenous languages.

\subsection{Primary and Secondary Education in the English-speaking System}

As concerns primary education, Cameroon's English-speaking system of education is made up of six years (formerly seven) that are concluded with the sitting of an official exam, which will enable successful students to obtain the so-called First School Leaving Certificate. It is very important to note here that, as its name entails, Anglophone primary education in Cameroon is taught entirely in English. Nevertheless, the author and his informants have observed that Cameroon Pidgin English or vernacular languages might be used informally by some teachers in the early years of primary education in rural areas where children have no exposure to standard English before they start attending formal education institutions. It was also noted that in French speaking areas, teachers may use French from time to time in order to communicate with young students who come from French-speaking families. Nevertheless, it is important to emphasize the fact that the use of languages other than English is totally informal and is even highly discouraged by members of the academic community (Alobwed'Epie, 1998).

ELIA Mon. I, pp. 65-88 DOI: http://dx.doi.org/10.12795/elia.mon.2019.i1.04 
When it comes to secondary education, English remains the medium of instruction from Form 1 to Upper Sixth (year 7). The study of English as a subject is compulsory from Form 1 to Form 5, at the end of which students are expected to sit the General Certificate of Education - Ordinary Level (GCEOL) exam. Successful students will then move to Sixth Form, made up of two years (Lower Sixth and Upper Sixth), which ends with the students' sitting the General Certificate of Education - Advanced Level (GCE-AL) exam.

As concerns languages, the situation witnessed in secondary schools is similar to that of primary schools, as English is consolidated as the sole medium of instruction throughout the seven years of education. The other official language, French, is taught as a compulsory subject in the first five years (up to Form Five) and becomes an optional subject in Sixth Form. It is also worth noting that the teaching of foreign languages (apart from Latin in some cases) is totally absent from the Anglophone system of education, which has made some authors insinuate that students going through the French-speaking system of education end up being more competent in foreign languages than their English-speaking counterparts (Echu, 2003: 42).

The emphasis on English as a medium of instruction in Cameroon's English-speaking system of education is again the direct result of colonial influence, as English-medium education gained ground during the colonial period. Before the British consolidated their rule in Southern Cameroons, missionary societies had opened several indigenous language schools which were relatively successful. In fact, as Todd (1982: 10) points out, 299 indigenous language schools, having a total of 7155 pupils, were registered in 1927. Surprisingly, by 1959, that number had plummeted to six schools and 191 students. This figure alone confirms Ndille's assumption that "it was never an intentional British colonial policy to harness the local languages into becoming the languages of instruction or official languages in their colonies" (2016: 21) and that the respective laws that tended to favour the promotion of indigenous languages were passed only for cosmetic purposes, with no real intention to enforce them.

\subsection{Immersion Programmes in Cameroon's System(s) of Education}

As witnessed above, we can clearly see that education in Cameroon is bilingual only when considering things from a general perspective.

ELIA Mon. I, pp. 65-88 DOI: http://dx.doi.org/10.12795/elia.mon.2019.i1.04 
Nevertheless, if one goes skin-deep one realizes that the country's education is clearly the combination of two monolingual systems with no relationship whatsoever with each other.

It is to deal with the above-mentioned situation that there have been various attempts from Cameroonian authorities to implement real immersion programmes which would eventually contribute to making Cameroonians perfectly bilingual. Therefore, right after the reunification of the former British and French Cameroons, government authorities opened schools aimed at setting the pace for the harmonization of the country's dual education system. In 1963 a pilot secondary school was opened in Man O' War Bay, followed by another one in Yaounde, known as Lycée Bilingue d'Application, opened in 1965. According to Bernard Fonlon, the English-speaking government official cum scholar who masterminded the system, a selected number of students from former French and British Cameroons were to be enrolled in the schools. During the first three years of secondary education, they would be taught separately in their respective first official languages, while receiving intensive language education in either French or English. Then both groups would be merged in the fourth year and would all sit the BEPC exam at the end of said year and the GCE-OL at the end of the fifth year. Then they might go further to take either the GCE-AL or Baccalauréat exams, or both. (Fonlon, 1969: 38). Unfortunately, Fonlon's immersion project did not last, and Cameroon's system of education went back to a situation where the French-medium and English-medium (sub)systems would evolve separately.

More recently, there has been another attempt to implement a new system of education which would again attempt to make students bilingual in the country's official languages. As opposed to Fonlon's system which was a combination of the Francophone and Anglophone systems, thus allowing students from both Francophone and Anglophone schools to come together and end up sitting the Brevet, GCE-O/L and Baccalauréat or GCE-A/L exams, today's bilingual system (which is still limited to a number of pilot schools) is different in the sense that students from Francophone schools will never actually find themselves in the same classroom as their peers from Anglophone schools. On the contrary, each sub-system selects students who would make up special bilingual classes

ELIA Mon. I, pp. 65-88～DOI: http://dx.doi.org/10.12795/elia.mon.2019.i1.04 
within those very sub-systems. Then in those bilingual classes about half of content subjects are taught in one official language or another.

\section{What about Indigenous Languages?}

From the above, we can clearly see that indigenous languages are completely overlooked in Cameroon's system of education. This quasi absence of indigenous languages in the country's classrooms seems to be a direct consequence of colonialism and the policies that were enforced in the British and French administered territories. As a matter of fact, though the British and the French had different approaches when it comes to administration, the presence of both colonial powers contributed to the consolidation of English and French as languages of education in the respective territories, thus creating the official bilingualism being witnessed in postcolonial Cameroon. Nevertheless, colonialism alone cannot fully explain the continuous importance of English and French in the country, as there is evidence of countries that broke away from systems of educations based on colonial languages and started using indigenous languages in education. One can mention at this juncture cases such as Tanzania that got its independence with an English-based education system but successfully moved to Swahili, which is nowadays the medium of instruction in Tanzanian schools (Rugemalira, 2013). In addition, in French-speaking Africa, Algeria's Arabization policy that led to the eradication of Frenchmedium instruction in favour of the use of Arabic has been implemented with great success (Benrabah, 2007). Thus, it is necessary to look at other factors beyond colonialism that might have contributed to consolidating the choice to stick to Cameroon's official English-French bilingualism.

\subsection{Reasons behind the Consolidation of Bilingualism after Independence}

There are various factors that have contributed to the consolidation of official bilingualism in education and the consistent marginalization of Cameroon's indigenous languages. Those factors can be grouped into two main categories, namely internal factors and external factors. When it comes to internal factors, they involve reasons underpinned by the complexity of the country's language situation and the need to consolidate ties between members of the Cameroonian nation. External factors mainly

ELIA Mon. I, pp. 65-88 DOI: http://dx.doi.org/10.12795/elia.mon.2019.i1.04 
involve Cameroon's relationship with its former colonial masters, neighbouring countries and international partners as well as the growing influence of one of its official languages (English) as a world lingua franca. These factors shall be revisited below.

\subsubsection{Internal Factors}

As mentioned above, there are various internal factors that have contributed to the consolidation of colonial bilingualism in Cameroon. One of these is the country's complex language situation.

According to researchers dedicated to the study of languages in Cameroon, the country is home to hundreds of indigenous languages, though there are conflicting figures when it comes to their exact number. In fact, Echu (2003) posits that the country is home to 247 languages, in addition to English, French and Cameroon Pidgin English, while as of 2019, Ethnologue talks of 270 indigenous languages being spoken (to varying degrees) in the country (Eberhard et al., 2019). This number is quite high, taking into account the fact that the country is home to about 25 million inhabitants (Kum Ngwoh, 2019). In addition, it is worth noting that there is no indigenous language whose use is spread across the national territory. In fact, most Cameroonian languages are spoken only amongst members of the same ethnic groups, with the exception of Fulfulde, Hausa, Mongo Ewondo and Duala to some extent.

After independence, one of the most important projects the country's first president had in mind was the formation of a strong nation where all members would feel a sense of belonging and cherish their living together. This policy, which is referred to as National Integration, was implemented as a reaction to the people's emphasis on ethnic rather than national affiliations. Though government authorities initially wanted to emphasize a return to purely African values and thus encouraged the teaching of a selected number of Cameroonian languages at university, this came to an end in 1977, as the teaching of some indigenous languages (which were closely tied to ethnic groups) became seen as a threat to national unity. In fact, as it was virtually impossible to select all the languages that make up the country's linguistic fabric, only a few ones had the privilege to be used in education, and this could possibly lead to complaints from members of

ELIA Mon. I, pp. 65-88 DOI: http://dx.doi.org/10.12795/elia.mon.2019.i1.04 
unrepresented languages, thus cementing ethnic sentiments over national ones. (Anchimbe, 2006a; Ndille 2016).

In addition, beyond identity construction issues, the multiplicity of Cameroon's indigenous languages has also posed a language planning problem which has further complicated the implementation of indigenouslanguage education. To be more specific, most indigenous languages in Cameroon have not been studied and standardized properly so as to be taught effectively in schools. Since most of them cannot even be taught as mere subjects, it would be very difficult to use Cameroon's indigenous languages as mediums of instruction. Cameroon is a low-medium income country which at the moment cannot afford a wide range language planning scheme which would involve the many vernacular languages being spoken in the country. Therefore, continuing with colonial mediums of instruction became the easy way to go.

The third internal factor that might have contributed to the neglect of indigenous languages in Cameroon's education system actually spans from all the reasons that have been mentioned earlier. In fact, since colonial times, indigenous languages were seen as less prestigious, and actually they were never called languages, but were referred to as "dialects" (in the whole country) or "patois" in the French speaking territory. This situation has not really improved nowadays. In fact, as indigenous languages have very little functional use in the country, their knowledge is not a prerequisite to be successful in society or achieve social mobility. English-French bilingualism is still preferred and encouraged in official parlance, and Cameroonians who wish to take up a position of significant importance in the administration are expected to master both colonial languages. As Anchimbe (2006b: 97) shows, English and French are the only languages used in written media, public examinations, court and justice, administration, and television. Indigenous languages might be used in church or on the radio, but it is only in music that they still enjoy a strong and consistent use. This official tendency to encourage the learning of only English and French has been fossilized in people's minds to the extent that most Cameroonians do not really see the importance of learning ethnic languages at schools. Therefore, based on the assumption that languages are only spoken when they provide avenues for their speakers' progress and wellbeing in society (Mufwene, 2001) it is no wonder that "[...] parents, schools, and the state on the other hand

ELIA Mon. I, pp. 65-88～DOI: http://dx.doi.org/10.12795/elia.mon.2019.i1.04 
are interested in the future of the children who learn [colonial languages]". (Anchimbe, 2006a: 136).

\subsubsection{External Factors}

Though internal factors have highly contributed to further grounding English-French bilingualism in Cameroon, it is also important to note that foreign influence has played a part in maintaining the status quo in the country. At this juncture, it is worth emphasizing the influence of French, British and American organizations, be they directly or indirectly related to government institutions. In addition, this section will also analyze the extent to which globalization has contributed to maintaining EnglishFrench bilingualism in Cameroon

\section{Soft-diplomacy from France and Francophonie}

Soft diplomacy has definitely fostered Cameroon's current official language and education policy. When it comes to France, it is worth noting that one of the main goals of the French Ministry of Foreign Affairs (known as Quai d'Orsay) is to promote and sustain the use of the French language around the world. Therefore, said institution has been involved in a lot of endeavours aimed at fostering the use of French in all spheres of life in former French colonies and other countries that had no colonial ties with France. As concerns Cameroon, the French Institute (Institut Françaisformerly known as Centre Culturel Français) has actively contributed to promoting the French language in the country through various schemes, such as the organization of cultural activities, including film projections or music concerts with a view to strengthening cultural ties between France and Cameroon and thus consolidating the use of the French language in the country. In addition, the French Ministry of Foreign Affairs has also contributed to the creation of various so-called Alliance FrancoCamerounaise (French-Cameroonian Alliance), which are social clubs and cultural centres having the same goals as the French Institute.

In addition to that, a few years after the creation of Francophonie, Cameroon joined as an Associate Member and has been a full-fledged member of the organization since November, 19 $9^{\text {th }} 1991$. Though Francophonie has been supporting Cameroon in various political and

ELIA Mon. I, pp. 65-88 DOI: http://dx.doi.org/10.12795/elia.mon.2019.i1.04 
socio-economic projects, it goes without saying that the organization's main activities in Cameroon revolve around the promotion of the French language by incentivizing French-language book publication and film production.

Finally, it is also worthy to note that by dint of the amount of French investment in Cameroon, France has a say in the country's economy. In fact, the French still dominate Cameroon's transport, agricultural and banking sectors and therefore have the ability to use that economic domination to exert political pressure on the government and promote the use of French in the country.

\section{Britain and America}

First of all, as we mentioned before, English is deeply grounded in the North-West and South-West Regions of the country, which made up the former British Southern Cameroons. In those two regions, the language enjoys some stability and is used (along with French in some cases) in all spheres of official life, education and in the media. Given Cameroon's historical relationship with the United Kingdom, the country became a member of the Commonwealth of Nations in 1995, being the first Commonwealth of Nations country to be part of Francophonie as well (Pondi, 1997).

As Francophonie, the Commonwealth of Nations is very active in activities aimed at encouraging cultural exchange between its members, which all (except Mozambique) have some colonial ties with the United Kingdom. The Commonwealth has been offering scholarships to Cameroonian students who wish to further their education in the United Kingdom, and it can be assumed that one of the Commonwealth's objectives is that once they complete their studies, these young graduates will return to Cameroon and contribute to spreading the use of the English language across the country. In fact, Commonwealth Day is celebrated in all Cameroonian Schools with different cultural activities which all hover around various aspects of the Anglo-Saxon culture, including the English Language.

In addition to cultural activities being promoted by the UK (through the Commonwealth of Nations), America has also contributed greatly to

ELIA Mon. I, pp. 65-88 DOI: http://dx.doi.org/10.12795/elia.mon.2019.i1.04 
the widespread interest in learning English being experienced across Cameroon's national territory. This has been made possible through the opening of various American Language and Cultural Centres (known as American Spaces) in Yaounde, Buea and Garoua, where English teachers are often given additional training, and even offered scholarships to travel to the USA and further their education. In addition, Americans have been very active in Cameroon through organizations such as the Peace Corps, that has been sending teachers to Cameroon for the past 62 years (Ashutantang, 2009).

Despite the efforts made by Cameroon's historical allies (Britain and America) to promote the use of English in the country, French has remained the most widely spoken language in Cameroon, leading to a situation of marginalization of the other official language (Ashutantang, 2009). Nevertheless, globalization is leading to a shift, with more and more people going for the English language (Kouega, 1999; Anchimbe, 2007).

\section{Globalization}

Globalization has confirmed English as the new world lingua franca. The language is now used for interactions at the international level in domains such as business, media and entertainment, just to name a few (Crystal, 1997). Nowadays, America's role in the spread of the English language is undeniable, as the dissemination of the country's culture (sport, music, cinematography, etc.) has contributed indirectly to increasing the prestige of the English language and making it more attractive. Therefore, even in situations where English was not the traditional language, the need to fit within international dynamics has made many people decide to go for the language. Cameroon became independent around the time America started gaining great influence around the world, thus grounding the English language as the world lingua franca. The presence of American teachers and other humanitarian workers, as well as the spread of American culture in the country has made many Cameroonians develop great interest in American English.

Presently, more and more Cameroonians from a French-speaking background are going for English-medium education. The above notwithstanding, there is a different trend when it comes to prestige between Francophone and Anglophone Cameroonians. Since English is

ELIA Mon. I, pp. 65-88～DOI: http://dx.doi.org/10.12795/elia.mon.2019.i1.04 
first and foremost a foreign language to Francophone Cameroonians who go for English-medium education, they seem to have a negative attitude towards the local variety of English and tend to highly regard American English (and British English as well). Therefore, the indigenes of the English-speaking part of the country are often shunned by these English speakers of Francophone background for speaking bad English (often sarcastically referred to as l'anglais de Bamenda) (Atechi, 2016). This situation is different in the English-speaking territory where a standard localized variety has been established, though one may still argue that foreign criteria, especially closeness to Standard British English, determined the choice of that variety. More specifically, English-speaking Cameroonians tend to have a better attitude towards the local variety, especially the one spoken around the coast, which is said to be less influenced by indigenous languages. The reason behind this speaks volumes about the status of indigenous languages in the country. In fact, Coastal varieties of Cameroon English are seen as more prestigious because they are allegedly less influenced by vernacular languages, as opposed to the varieties spoken in the savannah areas of English-speaking Cameroon, where vernacular languages still enjoy some strength.

\section{Conclusion: a Case for Indigenous Language Education in Cameroon}

Throughout this article, we have delved into Cameroon's bilingual education policy, investigating the historical, political and social factors that might have contributed to the current situation, which is manifested by emphasis on English-French bilingual education in a country where there are many indigenous languages that would represent better the country's intrinsic identity. The investigation of various documentary and nondocumentary sources has led to the conclusion that the dominance of English and French in the country is rooted in the country's colonial past and got consolidated by many factors, be they internal such as nation building goals against the backdrop of the country's complex language situation, or external, like pressure to fit within the ever increasing globalized world while maintaining a good relationship with former colonial master.

Unfortunately, the situation described above has taken a heavy toll on Cameroon's linguistic (and cultural) wealth, as evidenced by the

ELIA Mon. I, pp. 65-88 DOI: http://dx.doi.org/10.12795/elia.mon.2019.i1.04 
decreasing number of indigenous language speakers. Actually, based on figures obtained from Ethnologue, as of 2019, 76 indigenous languages spoken in Cameroon are said to be "in trouble", while 18 of them are dying. Furthermore, 9 of the country's 279 indigenous languages have no speakers left, making them dead (or extinct) languages (Eberhard et al., 2019). From the figures provided earlier, it can be concluded that a total of 94 indigenous languages currently spoken in Cameroon are on the brink of extinction, and if drastic changes are not made, this situation will probably get worse. As a matter of fact, Cameroon's official bilingualism and the relative absence of indigenous language education can be said to be the main reason behind this situation.

Many scholars have confirmed that indigenous language education may actually contribute to helping students develop better learning skills that would eventually help them in their academic and professional development. In fact, Cummins (1984) indicates that learning an indigenous language first may actually be the best way to be prepared cognitively to learn any other language. Children who are enrolled in English or Frenchonly primary education institutions do not always have the skills required to learn in a stress-free environment and therefore reach their highest potential. This may eventually cause serious learning issues which could eventually lead to school dropout.

Nevertheless, given Cameroon's situation, this (cognitive) linguistic argument may not be solid enough to advocate the teaching of indigenous languages, given the fact that nowadays, most children in the country start speaking (or receiving great input from) English and French at home, long before they actually start going to school. The foregoing notwithstanding, language cannot be separated from society and as such it is impossible to overlook the cultural consequences that indigenous language neglect has caused in Cameroon.

Virtually all members of the academic community are of the opinion that languages are not mere tools used for communication, but also reflect various aspects of culture and identity. As a matter of fact, according to the United Nations General Assembly paper titled "Expert Mechanism on the Rights of Indigenous Peoples: Study on the role of languages and culture in the promotion and protection of the rights and identity of indigenous peoples" (2012: 8).

ELIA Mon. I, pp. 65-88～DOI: http://dx.doi.org/10.12795/elia.mon.2019.i1.04 
Language is an essential part of, and intrinsically linked to, indigenous peoples' ways of life, culture and identities. Languages embody many indigenous values and concepts and contain indigenous peoples' histories and development. They are fundamental markers of indigenous peoples' distinctiveness and cohesiveness as peoples.

The above quote goes hand in glove with Fishman's assertion that "[...] a traditionally associated language is more than just a tool of communication... [It] is often viewed as a very specific gift, a marker of identity and a specific responsibility towards future generations" (2001: 5). It then becomes clear that the neglect and loss of some of Cameroon's indigenous languages has definitely led to a loss of a huge part of the country's identity, and that failure to overturn the situation will lead to more serious consequences. Therefore, though emphasizing English and French in education is cost effective and trouble-free, having the advantage of consolidating nation-building while providing Cameroonians with more opportunities in today's globalized world, it goes without saying that one thing is being lost, that is, the very essence of the many peoples who have existed long before Cameroon became a country.

It is thus necessary for Cameroon's decision makers, to carefully consider the situation at stake and decide whether ancestral heritage should be sacrificed on the altar of the need to speak foreign languages for instrumental purposes.

\section{References}

Alobwed'Epie. (1998). Banning Pidgin English in Cameroon? In English Today 53, 14(1), 54-60. https://doi.org/10.1017/s0266078400000742

Anchimbe, E. A. (2005). Multilingual backgrounds and the identity issue in Cameroon. $A S J U, 39(2), 33-48$.

Anchimbe, E. A. (2006). Socio-pragmatic Constraints to Native or Indigenous Language Education in Cameroon. In Arasanyin, O. \& Pemberton, M. (eds.) Selected Proceedings of the 36th Annual Conference on African Linguistics, 133-141.

ELIA Mon. I, pp. 65-88 DOI: http://dx.doi.org/10.12795/elia.mon.2019.i1.04 
Anchimbe, E. A. (2006b). Functional seclusion and the future of indigenous languages in Africa: the case of Cameroon. In Mugane, J., et al. (eds), Selected proceedings of the Annual Conference on African Linguistics, 94103.

Anchimbe, E. A. (2007). On Norms and Prejudices: The Notion of Maturation in New Englishes. Interlingüistica, 17, 151-160

Ashutantang, J.B. (2009). Landscaping Postcoloniality: the dissemination of Cameroon Anglophone literature. Bamenda: Langaa RPCIG.

Atechi, S. (2016). Attitudes of Anglophone and Francophone Cameroonians towards Cameroon English as a Model of English Language Teaching and Learning in Cameroon. Journal of Education and Practice, 7(13), 109-115.

Benrabah, M. (2007). Language-in-education Planning in Algeria: historical development and current issues. Language Policy, 6(2), 225-252. https:// doi.org/10.1007/s10993-007-9046-7

Crystal, D. (1997). English as a Global Language. Cambridge: Cambridge University Press

Cummins, J. (1984). Bilingual Education and Special Education: Issues in Assessment and Pedagogy. San Diego: College Hill

Eberhard, D. M., Simons, G. F. and Fennig, C. D. (eds.). 2019. Ethnologue: Languages of the World. Twenty-second edition. Dallas, Texas: SIL International. Online version: http://www.ethnologue.com

Echitchi, R. (2018). Semantic Extensions, Pidgins and Autonomy: a study of Kamtok. Munich: LINCOM Europa

Echu, G. (2003). Coping with multilingualism: trends in the evolution of language policy in Cameroon. In PhiN, 25, 31-46. http://www.fu-berlin.de/Phin/x/ dir.cgi?ptest.

Fishman, J. A. (2001). Why is it so hard to save a threatened language? In Fishman, J. A. (ed.), Can threatened languages be saved? 1-22.

Fonlon, B. (1963). A case for early bilingualism. Abbia, 4, 56-94.

ELIA Mon. I, pp. 65-88 DOI: http://dx.doi.org/10.12795/elia.mon.2019.i1.04 
Fonlon, B. The Language Problem in Cameroon (An Historical Perspective). Comparative Education, 1, 25-49. https://doi.org/10.1080/ 0305006690050105

Kouega, J-P. (1999). The Influence of French on Cameroon English: A Case Study of the Registers of Administration and Finance. In Echu, G. and Grundstrom, A. (eds.) Official Bilingualism and Linguistic Communication in Cameroon, 103-111.

Kouega, J. P. (2001). Pidgin facing death in Cameroon. Terralingua. Retrieved from: http://www.terralingua.org/DiscPapers/DiscPaper17.html

Kouega, J. P. (2003). English in francophone elementary grades in Cameroon. Language and Education, 17(6), 408-420. https://doi. org/10.1080/09500780308666860

Kum Ngwoh, V. (2019). The Realities of National Integration in Cameroon. International Journal of Humanities and Social Studies, 7(3), 285-294. https://doi.org/10.24940/theijhss/2019/v7/i3/hs1903-066

Michalopoulos, S. \& Papaioannou, E. (2016). The Long-Run Effects of the Scramble for Africa. American Economic Review, 106(7), 1802-1848. https://doi.org/10.1257/aer.20131311

Mufwene, S. (2001).The Ecology of Language Evolution. Cambridge: Cambridge University Press. https://doi.org/10.1017/CBO9780511612862

Ndille, R. (2016). English and French as Official Languages in Cameroon: the intentionality of colonial representations and the failure of a Camerooncentric identity. European Journal of Language Studies, 3(2), 17-34.

Ngoh, V. J. (1996). History of Cameroon Since 1800. Limbe: Pressbook.

Pondi, J. E. (1997). Cameroon and the Commonwealth of Nations. The Round Table: the Commonwealth Journal of International Affairs, 344, 563-570. https://doi.org/10.1080/00358539708454389

Rugemalira, J. (2013). Language Policy and Planning - The Tanzania experience. In Akumbu, P. \& Chiatoh, B. (eds.), Language Policies in Africa: perspectives for Cameroon. Kansas City: Miraclaire Publishing

ELIA Mon. I, pp. 65-88 DOI: http://dx.doi.org/10.12795/elia.mon.2019.i1.04 
Todd, L. (1982). Cameroon. (Varieties of English around the World. T1). Heildeberg: Groos

United Nations, General Assembly, Expert Mechanism on the Rights of Indigenous Peoples: Study on the role of languages and culture in the promotion and protection of the rights and identity of indigenous peoples $\mathrm{A} / \mathrm{HRC} /$ EMRIP/2012/3/

Weber, B. (2012). German colonial influences on, and representations of, Cameroon Pidgin English. In Anchimbe, E. A. (ed.) Language Contact in a Postcolonial Setting: The Linguistic and Social Context of English and Pidgin in Cameroon.269-296. https://doi.org/10.1515/9781614511199.269

First version received: September, 2019 Final version accepted: November, 2019 